\title{
Effect Vladimir Janda Balance Training on Postural Sway and Leg Muscle Strength
}

\author{
Anggi Setiorini $i^{1,3}$, Denny Agustiningsih², Junaedy Yunus ${ }^{3}$ D, Santosa Budiharjo ${ }^{3}$ \\ ${ }^{1}$ Department of Anatomy, Faculty Medicine, Universitas Lampung, Lampung, Indonesia; ${ }^{2}$ Departement of Physiology, Faculty \\ of Medicine, Public Health and Nursing, Universitas Gadjah Mada, Yogyakarta, Indonesia; ${ }^{3}$ Department of Anatomy, Faculty of \\ Medicine, Public Health and Nursing, Universitas Gadjah Mada, Yogyakarta, Indonesia
}

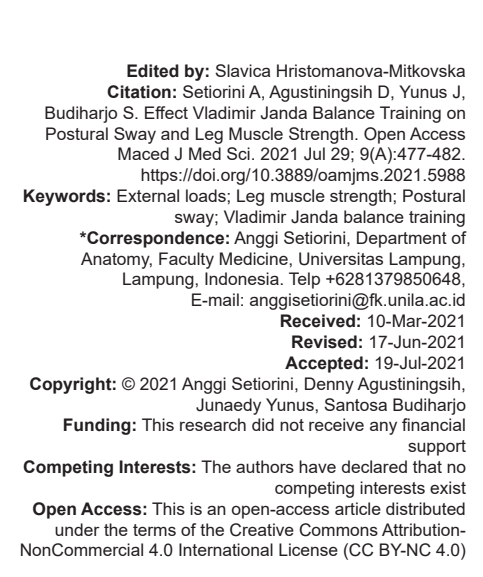

\section{Introduction}

Indonesia is an agricultural country and was predominately livelihood in agriculture. One of the estates that had the greatest contribution to national revenue is a tea plantation [1]. Kemuning Tea Plantation located in Ngargoyoso, Karanganyar, located on the east and from 7.400 to 7.600 from 11.100 to 11.2500 LS with an altitude of about 800-1540 m above the surface sea and slope of $45^{\circ}$. Strip area, in this area a path straight down or uphill and winding also slippery [2].

The majority of workers on tea plantations is a picker [3]. Tea pickers work with containers strapped to his back and began to pluck tea from the top downwards with the load of tea in the back. Position carries a heavy load on your back and the road is quite dangerous for the tea pickers sometimes cause problems for the tea pickers [4].

The large external loads can affect the postural control because it can improve postural sway because the center of mass is too close to the base of pressure [5].
Postural sway increased after the neck muscle fatigue [6]. External loads can cause musculoskeletal disorders in the upper and lower extremities and usually, the incidence is higher in women than men [7].

Balance exercise is a physical activity that is done to improve the stability of the body by improving lower extremity muscle strength balance exercises [8]. The basic approach was first developed by Dr. Vladimir Janda who is an expert on psychiatry and neurology that come from the Czech Republic. Balance training consists of five phases which is I-IV referred to as the exercise phase conducted over 4 weeks and phase $\mathrm{V}$ is referred to as the maintenance phase carried out for 1 week [9].

The balance exercise using the Vladimir Janda method consisted of five phase which were carried out for 5 weeks. Phases I-IV are carried out for 4 weeks, namely, five times a week, and phase $\mathrm{V}$ is carried out in the $5^{\text {th }}$ week, namely, three times a week. This exercise has movements that are carried out on the floor surface and the surface of the balance board [10]. Exercise using a balance board can also strengthen the 
core muscles or the muscles around the abdomen and back, not only the core muscles but can also increase the strength of the lower extremity muscles. In addition, balance board exercises are very helpful in preventing injuries and can maintain postural stability [11].

The movement of balance exercises on the surface of the balance board consists of six movements:

1. Stand up with one leg raised

2. Stand by lifting one leg and then swinging the leg

3. Stand by bending your knees a $30-45^{\circ}$ angle (single leg squat) and lifting the other leg

4. Stand on both feet while rotating the balance board

5. Stand on one leg while rotating the balance board

6. Stand up by lifting one leg while doing the activity [10].

\section{Methods}

The research design used was a quasiexperimental design with randomized control group pretest-posttest design. This research has earned a Certificate of Ethical Clearence from the Ethics Committee of the Medical Research Health, Faculty of Medicine, Universitas Gadjah Mada in Ref number: KE/FK/880/EC/2016. Participants were tea picker who is in Karanganyar Kemuning tea plantation with a work area on the slope $45^{\circ}$. Participants were divided into two groups: a control group of 15 people and the treatment group of 15 people and all are women. The control group was given without the Vladimir Janda balance training method while the treatment group was given exercises Vladimir Janda balance training over 5 weeks in which each training session takes as much as $15 \mathrm{~min}$

The population in this study was 70 tea pickers who were in the Kemuning tea plantation. There were 70 tea pickers met the criteria desired by the researchers, namely, 30 people, inclusion criteria: (1) The participants is a tea picker at the Kemuning tea plantation, Karanganyar with a basket carrying a basket, (2) Participants aged 25-40 years, (3) The participant is in good health (blood pressure: $120 / 80 \mathrm{mmHg}$, weight: normal according to body mass index (BMI), (4) The working hours of the research participants are $6 \mathrm{~h}$ per day, (5) Have worked as a tea picker for more than 2 years, (6) participants are willing to participate in research and are willing to cooperate and actively provide information. The exclusion criteria: (1) The participant has a balance disorder, (2) The participant has a dual profession other than as a tea picker, (3) The participant has posture disorders and body defects, and after using the calculation formula, a sample of 27 people was obtained. Anticipating dropout, the number of samples needs to be added by $5-10 \%$ so as not to interfere with the research results. The sample size of the study was calculated using the formula for the sample size for experimental research.

$$
\mathrm{n}=\frac{\mathrm{N}}{1+\mathrm{N}\left(\mathrm{d}^{2}\right)}
$$

\section{External load analysis}

The use of external load in the form of transport equipment such as bags made from parachute material base used to collect the result of the passage of tea leaves. How external load measurement in this study by taking the average weight of the entire participant of study during the week and use units kilograms.

\section{Analysis of postural sway}

The frequency of postural sway in the value of using posturometer. Measurements using posturometer by means of research participants posturometer stands above board and will be assessed when the subject began to fall. The unit used to assess postural sway in this research is seconds. This measurement is done three times repetition and will take the best value.

\section{Leg muscle strength analysis}

Muscular strength in this research is the energy released by muscles when performing pull the leg dynamometer to the fullest. Measurement is performed three times and muscle strength is known from the highest rate shown on the dynamometer needle in kilograms. Measurements were performed 3 times repetition and will take the best value.

\section{Balance exercise training}

Vladimir Janda balance training method is a balance training program that has a lot of variations of movement. Vladimir Janda balance training method consists of five phases carried out for 5 weeks. Phase I-IV conducted over 5 times a week, phase $V$ was conducted three times in a week. Each exercise is performed for $30 \mathrm{~s}$ each leg and resting for $30 \mathrm{~s}$ before the next leg and using tools such as balance boards. This exercise is carried out for 15 min each session.

\section{Analysis results}

The data collected, then conducted tests of normality using the Shapiro-Wilk. If the data were 
normally distributed then continued by independent t-test. If the data are not normal then using the MannWhitney test. To determine the predictive variables then performed multivariate logistic regression analysis.

\section{Results}

Characteristics of research participants in the control group and the treatment group at the beginning of the study can be shown in Table 1.

Table 1: Characteristics of research subjects

\begin{tabular}{lllll}
\hline Variable & \multicolumn{2}{l}{ Groups } & $\mathrm{p}$ \\
\cline { 2 - 2 } & Control & & Treatment & \\
\cline { 2 - 2 } & Mean $\pm \mathrm{SD}$ & & Mean $\pm \mathrm{SD}$ & \\
\hline Age (year) & $40.6 \pm 3.66$ & & $39 \pm 3.74$ & 0.161 \\
$\mathrm{BMI}\left(\mathrm{kg} / \mathrm{m}^{2}\right)$ & $23.34 \pm 1.63$ & & $21.05 \pm 1.80$ & 1.00 \\
Duration of the work (year) & $18.2 \pm 7.75$ & & $20.26 \pm 7.85$ & 0.624 \\
Working time (hour) & $6.46 \pm 0.71$ & & $6.53 \pm 0.80$ & 0.935 \\
Postural Sway (second) & $3.3 \pm 1.34$ & & $11.96 \pm 6.76$ & 0.019 \\
Muscle strengthen of knee extensor $(\mathrm{kg})$ & $33.93 \pm 13.77$ & & $50.97 \pm 24.57$ & 0.009 \\
Muscle Strengthen of dorsifleksor $(\mathrm{kg})$ & $1,15 \pm 0,42$ & & $3.57 \pm 2.01$ & 0.00 \\
\hline
\end{tabular}

Statistically age, BMI, the length of employment, and working time in each group had no significant difference $(p>0.05)$.

The influence of external load on postural sway and the effect of balance exercises Vladimir Janda training to postural sway either no load or with the load.

Table 2: Results of analysis of postural sway control group and treatment

\begin{tabular}{|c|c|c|c|c|c|c|c|c|}
\hline \multirow[t]{3}{*}{ Variable } & \multicolumn{4}{|c|}{ Control Mean \pm SD } & \multicolumn{4}{|c|}{ Treatment Mean \pm SD } \\
\hline & \multicolumn{2}{|c|}{ Without Load } & \multicolumn{2}{|c|}{ With Load } & \multicolumn{2}{|c|}{ Without Load } & \multicolumn{2}{|c|}{ With Load } \\
\hline & Pre-test & $\begin{array}{l}\text { Post- } \\
\text { test }\end{array}$ & $\begin{array}{l}\text { Pre- } \\
\text { test }\end{array}$ & $\begin{array}{l}\text { Post- } \\
\text { test }\end{array}$ & $\begin{array}{l}\text { Pre- } \\
\text { test }\end{array}$ & $\begin{array}{l}\text { Post- } \\
\text { test }\end{array}$ & $\begin{array}{l}\text { Pre- } \\
\text { test }\end{array}$ & $\begin{array}{l}\text { Post- } \\
\text { test }\end{array}$ \\
\hline $\begin{array}{l}\text { Postural } \\
\text { sway } \\
\text { (second) }\end{array}$ & $\begin{array}{l}3.93 \pm \\
1.48\end{array}$ & $\begin{array}{l}6.8 \pm \\
5.39\end{array}$ & $\begin{array}{l}1.86 \pm \\
0.61\end{array}$ & $\begin{array}{l}3.4 \pm \\
1.14\end{array}$ & $\begin{array}{l}2.66 \pm \\
0.69\end{array}$ & $\begin{array}{l}17.1 \pm \\
2.44\end{array}$ & $\begin{array}{l}1.53 \pm \\
0.80\end{array}$ & $\begin{array}{l}12.73 \pm \\
1.61\end{array}$ \\
\hline
\end{tabular}

Mann-Whitney test results in the control and treatment groups with weights at the end of the study also showed a significant $(p<0.05)$, namely, Vladimir Janda balance training can reduce postural sway (Table 2 ).

Effect of balance exercises Vladimir Janda training to leg muscle strength is the strength of the knee extensor muscles and flexor ankle dorsi.

Table 3: Results of analysis of muscle strength knee extensor and treatment control group

\begin{tabular}{|c|c|c|c|c|c|c|c|c|}
\hline \multirow[t]{3}{*}{ Variable } & \multicolumn{4}{|c|}{ Control Mean \pm SD } & \multicolumn{4}{|c|}{ Treatment Mean \pm SD } \\
\hline & \multicolumn{2}{|c|}{ Without load } & \multicolumn{2}{|c|}{ With load } & \multicolumn{2}{|c|}{ Without load } & \multicolumn{2}{|c|}{ With load } \\
\hline & Pre-test & $\begin{array}{l}\text { Post- } \\
\text { test }\end{array}$ & $\begin{array}{l}\text { Pre- } \\
\text { test }\end{array}$ & $\begin{array}{l}\text { Post- } \\
\text { test }\end{array}$ & $\begin{array}{l}\text { Pre- } \\
\text { test }\end{array}$ & $\begin{array}{l}\text { Post- } \\
\text { test }\end{array}$ & $\begin{array}{l}\text { Pre- } \\
\text { test }\end{array}$ & $\begin{array}{l}\text { Post- } \\
\text { test }\end{array}$ \\
\hline iscle & $27.6 \pm$ & $30.7 \pm$ & $19.6 \pm$ & $25.2 \pm$ & $40.2 \pm$ & $71.2 \pm$ & $28.1 \pm$ & $52.9 \pm$ \\
\hline $\begin{array}{l}\text { strengthen knee } \\
\text { extensor }(\mathrm{kg})\end{array}$ & 10.09 & 10.16 & 9.59 & 13.1 & 13.58 & 15.66 & 11.69 & 14.4 \\
\hline
\end{tabular}

Independent test results of t-test in the control and treatment groups at the end of the study had significant results ( $p<0.05)$, namely, Vladimir Janda balance training can improve the strength of the knee extensor muscles (Table 3).

Mann-Whitney test results in the control and treatment groups at the end of the study there were significant differences $(p<0.05)$, namely Vladimir Janda balance training can improve muscle strength ankle dorsiflexor (Table 4).

Table 4: Results analysis Dorsi muscle strength ankle flexor in control group and the treatment group

\begin{tabular}{llllll}
\hline Variable & \multicolumn{2}{l}{ Control Mean \pm SD } & & \multicolumn{2}{l}{ Treatment Mean \pm SD } \\
\cline { 2 - 3 } & Pre-test & Post-test & & Pre-test & Post-test \\
\hline $\begin{array}{l}\text { Muscle strengthen } \\
\text { dorsi ankle flexor }(\mathrm{kg})\end{array}$ & $1.26 \pm 0.44$ & $2.16 \pm 1.33$ & & $1.03 \pm 0.33$ & $4.96 \pm 1.44$ \\
\hline
\end{tabular}

Logistic regression test results below show the receiver operating characteristics ( $R O C$ ) value found in models 3 was 0.917 which if interpreted the variables that are in model 3 that is postural sway with the weight and strength of the knee extensor muscles can be affected by Vladimir Jandabalance training of $91.7 \%$, $8.3 \%$ while the others can be influenced by other factors outside Vladimir Janda balance training, such as activity outside exercise, nutrition, and environmental conditions (Table 5).

Table 5: Result analysis multivariate logistic regression

\begin{tabular}{llll}
\hline Model & OR & Cl 95\% & \\
\cline { 4 - 4 } & & Min & Max \\
\hline Model 1 & 0.037 & 0.00 & 0.00 \\
$\quad$ Postural sway without load & 0.00 & 0.00 & 0.00 \\
Postural sway with load & 0.00 & 0.00 & 0.00 \\
$\quad$ Muscle strengthen knee extensor & 0.206 & 0.00 & 0.00 \\
$\quad$ Muscle strengthen dorsi ankle flexor* & & & \\
Model 2 & 0.046 & 0.00 & 0.00 \\
$\quad$ Postural sway without load* & 0.00 & 0.00 & 0.00 \\
$\quad$ Postural sway with load & 0.00 & 0.00 & 0.00 \\
$\quad$ Muscle strengthen knee extensor & 0.00 & 0.00 & 0.00 \\
Model 3 & 0.00 & 0.00 & 0.00 \\
$\quad$ Postural sway with load & 0.917 & & \\
$\quad$ Muscle strengthen knee extensor & & & \\
$\quad$ ROC & &
\end{tabular}

\section{Discussion}

\section{Influence of external expenses on postural}

sway

The results of this study indicate postural sway without load and the load on the control and treatment groups yielded significant results $(p<0.05)$. An external imposition that occurs in the tea pickers can improve postural sway toward research participants both the control group and the treatment group. The external load can affect the musculoskeletal system. Response postural muscles synergistic leads to time and distance from the activity of the muscle groups needed to maintain balance and posture control [12].

External load limit recommended for women is $30 \%$ of the body weight. Based on the age limit of the load may be appointed legally by the internationally were women aged 16-18 years maximum lifting load $11 \mathrm{~kg}$ while for women aged above 18 years maximum lifting load is $16 \mathrm{~kg}$ [13].

The use of excessive external loads can cause postural deviations [14]. Backpacks resulted in 
increased working the rectus abdominis muscle in an attempt to balance the body due to the changing center of gravity of the body [15]. The use of a backpack can improve extension of the neck and torso is inclined forward toward the anterior as well as their tendency to increase [16]. External loads can cause musculoskeletal disorder [7]. Postural sway increases after experiencing neck muscle fatigue [6]

Takes lumbar flexion can increase the burden on the backs of postural sway both in obese children and children with normal weight. This is caused by lower leg muscle strength is decreased due to the weight of the body must bear the child itself (internal force) [17]. Comparison between carrying loads on their backs or posterior and anterior to the load $15 \%$ of body weight showed that carrying the load on his back can increase hip flexion with the head inclined forward so that can affect the body postural control [18].

\section{Effect of balance exercise methods Vladimir Janda of the postural sway and a limb muscle strength}

The results of this study indicate that prior to study both the control group and the treatment group showed that there is no considerable difference between the two groups, while at the end of the study showed that considerable differences between the control group and the treatment group. The results are consistent with previous research which states that the balance training methods Vladimir Janda play an important role in the process of proprioception on the human body, where proprioception has a role in maintaining the balance postural [9].

Assessment of postural sway is needed to prevent falls. If the body sways when walking so the risk of falling, it is necessary to exercise aid. Rate gait must also be done carefully, to see how to set footwell, not so easily swayed while standing, lift the right leg with the foot while walking, lower extremity muscle strength is strong enough to walk without helping [19].

The stability of postural sway in the treatment group supported by the influence of Vladimir Janda balance training method which improves static and dynamic balance [20]. Exercise conducted over 4 weeks is enough to reduce postural sway in healthy adolescents [21]. The exercise program coupled with improved input sensory very significant in improving the balance of the body [22]. Interventions that can sufficiently increase the strength of postural control [23].

Lower extremity muscle strength is one important factor to maintain a balance that can be portrayed through the power of the flexor/extensor knee relevant to increase the strength of the knee extensor muscle strength of this study [24]. Addition affected by age and gender is also influenced by factors such as biomechanical factors, factors neuromuscular and metabolic factors [25]. The human skeletal muscle metabolism during exercise will change in altitude, hot and cold [26].

Muscle strength can be improved by doing an exercise routine exercise [25]. Minimal muscle power for 4 weeks had a positive impact in improving muscle strength [27]. Stand with both feet on the field unstable/contraction of muscle tibialis anterior (TA), soleus,and the peroneus longus which is recorded in the activity electromyography, it shows the muscles of the lower extremities is very instrumental to maintain the dynamic balance [28]. Exercise regularly with the imposition of $25-100 \%$ can increase muscle strength. The muscle strength of the legs, knees, and hips should be adequate to maintain the body balance when the force from outside. Muscle strength is directly related to the ability of muscles to overcome a force gravity and the other external loads that continuously affect the position of the body [29].

Exercise causes adaptation, namely the increasing movement mechanics. The basic principle of an exercise is based on the body as a biological system, to function optimally as a consequence of adaptation in response to exercise. Body Mechanics is an attempt to coordinate the musculoskeletal system and the nervous system in maintaining balance, posture, and body alignment during lifting, bending, moving, and perform daily activities [30].

\section{Conclusion}

Based on these results it can be concluded

that:

1. The use of external load in the control group and the treatment group improves postural sway

2. Exercise balance Vladimir Janda method can reduce postural sway in the treatment group

3. Exercise balance Vladimir Janda method can increase leg muscle strength as the strength of the knee extensor muscles and flexor ankle dorsi muscle in the treatment group

4. The increase in leg muscle strength is the strength of the knee extensor muscles and flexor ankle dorsi muscle after exercise balance Vladimir Janda method can reduce postural sway in the treatment group.

\section{Acknowledgment}

The author would like to thank Mr. Prianto and Mr. Purwoto who helped to prepare the equipment 
at Plantation Kemuning and Wiwit Ananda Wahyu S which has been helpful in teaching data analysis using SPSS.

\section{References}

1. Rosida A. Pengaruh Faktor Internal Konsumen dan Kinerja Bauran Pemasaran Terhadap Keputusan Pembelian Komoditas Teh oleh Konsumen Rumah Tangga di Provinsi Jawa Barat. Bandung: Universitas Padjajaran; 2006. https://doi. org/10.30587/matrik.v21i2.1663

2. Karanganyar PK. Wisata Perkebunan Teh Karanganyar. Karanganyar PK; 2015.

3. Rakhmayanti A. Pengaruh Budaya Terhadap Kinerja Pemetik Teh. Pagilaran, Batang: Rakhmayanti A; 2014.

4. Yulitania DD. Perbedaan Pengaruh Peregangan dan William Flexion Exercise Terhadap Nyeri Punggung Bawah Non Spesifik Pada Pemetik Teh di Perkebunan Teh Jamus. Surakarta: Universitas Muhammadiyah Surakarta; 2015. https://doi. org/10.37341/interest.v6i1.93

5. Qu X, Nussbaum MA. Effects of external loads on balance control during upright stance: Experimental results and modelbased predictions. Gait Posture. 2009;29(1):23-30. https://doi. org/10.1016/j.gaitpost.2008.05.014

\section{PMid:18632273}

6. Schiepatti M, Nardone A, Schmid M. Neck muscle fatigue affects postural control in man. Neuroscience. 2013;121(2):27785. https://doi.org/10.1016/s0306-4522(03)00439-1 PMid: 14521987

7. Simpson KM, Munro BJ, Steele J. Effect of load mass on posture, heart rate and subjective responses of recreational female hikers to prolonged load carriage. Appl Ergon. 2011;42(3):40310. https://doi.org/10.1016/j.apergo.2010.08.018 PMid:20870217

8. Masitoh I. Fenomena Balance Exercise Untuk Meningkatkan Keseimbangan Postural Lanjut Usia; 2013.

9. Page P. Sensorimotor training: A eningkatkan Keseimbangan Post training. J Bodywork Movement Ther. 2006;10:77-84. https://doi.org/10.1016/j.jbmt.2005.04.006

10. Muscles JV. Central nervous motor regulation and back problems. In: The Neurobiologic Mechanisms in Manipulative Therapy. Boston, MA: Springer US; 1978. p. 27-41. Available from: http://www.link.springer.com/10.1007/978-1-4684-89026 2. https://doi.org/10.1007/978-1-4684-8902-6 2. [Last accessed on 2021 Jun 17]

11. Janda V. On the concept of postural muscles and posture in man. Aust J Physiother. 1983;29(3):83-4.

PMid:25025491

12. Ting $\mathrm{M}, \mathrm{McPherson} \mathrm{J}$. A limited set of muscle synergies for force control during a postural task. J Neurophysiol. 2005;93(1):60913. https://doi.org/10.1152/jn.00681.2004

PMid: 15342720

13. Rugelj D, Sevrg/10.1152/jn.00681.2load mass and its placement on postural sway. Appl Ergon. 2011;42(6):860-6. https://doi. org/10.1016/j.apergo.2011.02.002 PMid:21356532

14. Grimmer K, Danise B, Milanese S, Pirunsan U, Tront P. Adolescent standing postural response to backpack loadsand its placement on postural swamental study. BMC Musculosc Disord. 2002;3:10. https://doi.org/10.1186/1471-2474-3-10

\section{PMid:11960561}

15. Goh JH, Thambyah A, Bose K. Effects of varying backpack loads on peak forces in the lumbosacral spine during walking. Clin Biomech (Bristol, Avon). 1998;13(Suppl 1):S26-31. https:// doi.org/10.1016/s0268-0033(97)00071-5 PMid: 11430787

16. Chow DHK, Li MF, Lai A, Pope MH. Effect of load carriage on spinal compression. Int J Ind Ergon. 2011;41(3):219-23.

17. Pau M, Kim S, Nussbaum MA. Does load carriage differentially alter postural sway in overweight vs. normal-weight schoolchildren? Gait Posture. 2012;35(3):378-82. https://doi. org/10.1016/j.gaitpost.2011.10.354 PMid:22088849

18. Fiolkowski P, Horodyski M, Bishop M, Williams M, Stylianou L. Changes in gait kinematics and posture with the use of a front pack. Ergonomics. 2006;49(9):885-94. https://doi. org/10.1080/00140130600667444

\section{PMid:16801234}

19. Hwang S, Agada P, Kiemel T, Jeka JJ. Identification of the unstable human postural control system. Front Syst Neurosci. 2016;10:22. https://doi.org/10.3389/fnsys.2016.00022 PMid:27013990

20. Emery C, Cassidy J, Klassen T, Rosychuk R, Rowe B. Effect of a home-based balance training program in reducing sports related injuries among healthy adolescents: A cluster randomized controlled trial. CMAJ. 2005;172(6):749-54. https:// doi.org/10.1503/cmaj.1040805

PMid: 15767608

21. Yaggie JA, Campbell BM. Effects of balance training on selected skills. J Strength Cond Res. 2006;20(2):422-8. https:// doi.org/10.1519/r-17294.1

\section{PMid: 16686574}

22. Nepocatych S, Ketcham CJ, Vallabhajosula S, Balilionis G. The effects of unstable surface balance training on postural sway, stability, functional ability and flexibility in women. J Sports Med Phys Fitness. 2018;58(1-2):27-34. https://doi.org/10.1249/01. mss.0000478570.20691.33

\section{PMid:27991482}

23. Venetsanou F. Effect of an exercise program emphasing coordination on preschoolerssurface balance training on postural sway, stabilit-55.

24. Katayama Y, Senda M, Hamada M, Kataoka M, Shintani M, Inoue $\mathrm{H}$. Relationship between postural balance and knee and toe muscle power in young women. Acta Med Okayama. 2004;58(4):189-95

PMid: 15551756

25. Ganong W.F. Review of medical physiology. In: Review of Medical Physiology. $22^{\text {nd }}$ ed. New York: McGraw Hill Companies; 2005.

26. Clarys JP, Alewaeters K, Zinzen E. The influence of geographic variations on the muscular activity in selected sports movements. J Electromyogr Kinesiol. 2001;11(6):451-7. https:// doi.org/10.1016/s1050-6411(01)00020-7

PMid:11738957

27. Dankel SJ, Jessee MB, Mattocks KT, Mouser JG, Counts BR, Buckner SL, et al. Training to fatigue: The answer for standardization when assessing muscle hypertrophy? Sport Med. 2016;47(6):1021-7. https://doi.org/10.1007/ s40279-016-0633-7 PMid:27677915

28. Sozzi S, Honeine J-L, Do M-C, Schieppati M. Leg muscle activity during tandem stance and the control of body balance in the frontal plane. Clin Neurophysiol. 2013;124(6):1175-86. https://doi.org/10.1016/j.clinph.2012.12.001 
PMid:23294550

29. Skelton D. Tailored group exercise (falls management exercise-FaME) reduces falls in community-dwelling older frequent fallers (an RCT). Age Ageing. 2005;34(6):636-9. https://doi. org/10.1093/ageing/afi174

PMid:16267192
30. SerráerrV, da SerráerrR, Foerster B, Tann.1093/Pedro VM, Salvini TF. Assessment of the quadriceps femoris muscle in women after injury induced by maximal eccentric isokinetic exercise with low angular speed. J Sports Sci Med. 2007;6(1):10616. https://doi.org/10.1590/s0100-879x2003000600014 PMid:24149232 